Dhaka Univ. J. Biol. Sci. 25(1): 65-73, 2016 (January)

\title{
EFFECTS OF SALINITY CHANGES ON GROWTH PERFORMANCE AND SURVIVAL OF CLIMBING PERCH, ANABAS TESTUDINEUS (BLOCH, 1795)
}

\author{
Faijun Nahar, Wahida Haque, Dewan Ali Ahsan and Md. Ghulam Mustafa* \\ Department of Fisheries, University of Dhaka, Dhaka 1000, Bangladesh
}

Key words: Aquaculture, Effects of salinity, Survival, Growth

\begin{abstract}
An experiment was carried out to find the salinity tolerance capability and growth performance of Climbing Perch, Anabas testudineus (Bloch, 1795). Anabas testudineus commonly cultured fish in Bangladesh was reared in laboratory conditions at different salinities of $0,3,6,9,12,15,18$ and $21 \%$ of 60 days. Hundred per cent survivals were detected at $0,3,6$ and $9 \%$ salinity while $100 \%$ mortality was recorded at 18 and $21 \%$ salinity. Various responses to threat and feeding were observed among the fish in different treatments. Lowest feed conversion ratio was found in the control group while the highest was detected at $15 \%$ salinity. On the other hand, decreasing trend of specific growth and average growth rate were observed in $A$. testudineus fingerlings from 0 to $15 \%$ salinity. Significantly higher specific growth rate and average growth rate were detected in A. testudineus fingerlings reared at $0-6 \%$ salinity $(\mathrm{p}<0.05)$. The present study suggests that Climbing Perch fingerlings can be reared at fresh water growth rates in coastal water with salinity up to $6 \%$.
\end{abstract}

\section{Introduction}

Climbing Perch (Anabas testudineus) commonly known as Koi fish in Bangladesh is highly delicious and having high consumer demand. As a freshwater fish species Anabas testudineus is included in Perciformes order under Anabantidae family. Freshwater fish is of much importance to the national economy. The water salinity affects the fish directly or indirectly through generating changes in the ecological factors and production of food organisms. A change in salinity affects the survival and growth of fish. ${ }^{(1)}$ Due to these high levels of salinity, the traditionally cultured fish species fall under stress and cannot perform well. So, they have shown stunted growth and low production. Effects of salinity was widely reported on oxygen, $\mathrm{pH}$, temperature and specific gravity by Nikolsky ${ }^{(2)}$, on gametes and fertilization period of the fish by Holliday(3), on behavioral response by Baggerman ${ }^{(4)}$. For salt-water aqua-culturists, it is important to determine the threshold levels and to establish the optimal requirements for salt contents of the cultured fishes. However, very limited research has been conducted on the effect of salinity on survival and growth of Climbing Perch. Therefore, the overall objective of this study was to investigate how salinity affects the growth of $A$. testudineus fingerlings in culture condition.

*Author for correspondence: <mghulam@du.ac.bd> 


\section{Materials and Methods}

Four hundred A. testudineus fingerlings were collected from a reputable fish hatchery in Mymensingh, Bangladesh. The fingerlings were acclimatized for a period of 72 hours prior to the start of the experiment in the acclimatization tank. The brine solution was prepared in the circular tank by adding commercial grade $\mathrm{NaCl}$ until the selected level of salinity was achieved. The salinity level was measured by a salinity meter. There were 8 sets ( 2 replica in each set, 8 sets $=1$ control +7 treatments) of aquariums having the capacity of 60 liters of water and stocked with 10 fish in each. Replacement of water from each aquarium was done every 7 days by siphoning the bottom of the aquariums at 60 days rearing period. To determine the effect of salinity, fingerlings were exposed to $0,3,6,9,12,15,18$ and $21 \%$ o salinity under two replicates for a 60 day rearing period in the laboratory. For the purpose of conditioning 300 liters static rectangular plastic tank was used. At first the fish fingerlings were released into the plastic tank at $0 \%$ salinity. After 48 hours of acclimatization 10 fish fingerling were released to the $0 \%$ labeled aquarium and the rest of the fingerlings were kept inside the plastic tank where salinity level was increased from 0 to $3 \%$ for the next 48 hours. After another 48 hours of acclimatization 10 fish fingerlings were released to the 3\%o labeled aquarium and the rest of the fingerlings were again kept inside the plastic tank where salinity level was increased from 3 to $6 \%$ for the next 48 hours. By following this procedure the salinity was raised up to $21 \%$. Finally the mortality and response of the fishes were observed at different salinities. Sampling was made at the 15, 30, 45 and 60th day of the experimental period and individual length and weight of fish were recorded. Water quality parameters during the period of this study were from $\mathrm{pH} 8.1$ to 9.6, DO 5.5 to $7.95 \mathrm{mg} / \mathrm{l}$ and temperature 25.10 to $31.20^{\circ} \mathrm{C}$. The fish were fed fish feed meal of $50 \%$ crude protein (CP) at $5 \%$ of total body weight. Weight gain was calculated by subtracting the initial mean weight from the final mean weight. Specific growth rate (SGR), feed conversion ratio (FCR) and average growth rate (AGR) were calculated at the end of each experiment for each salinity using the formulae reported by Hopkins ${ }^{(5)}$.

SGR $(\%)=\left(\operatorname{In} W_{2}-\ln W_{1}\right) /\left(T_{2}-T_{1}\right) \times 100$, where, $W_{1}=$ Initial weight $(g), W_{2}=$ Final weight $(\mathrm{g}), \mathrm{T}_{1}=$ Initial time (day) and $\mathrm{T}_{2}=$ Final time (day).

FCR $=$ Feed $(g)$ consumed by the fish $/\left(W_{2}-W_{1}\right)$, where, $W_{1}=$ Initial weight $(g)$ and $W_{2}$ $=$ Final weight $(\mathrm{g})$.

AGR $=\left(W_{2}-W_{1}\right) /\left(T_{2}-T_{1}\right)$, where, $W_{1}=$ Initial weight $(g), W_{2}=$ Final weight $(g), T_{1}=$ Initial time (day) and $\mathrm{T}_{2}=$ Final time (day).

\section{Results and Discussion}

During 60 days rearing period all fingerlings survived in 0 to $9 \%$ o salinities. In $12 \%$ o salinity survival rate at 15 days was $85 \%$ and then decreased up to $60 \%$ at 60 days. At $15 \%$ salinity survival rate was $75 \%$ at 15 days and then decreased up to $20 \%$ at 60 days 
(Table 1). At $18 \%$ salinity survival rate was $100 \%$ up to 2 days and then dropped to $20 \%$ on the 3rd day and $0 \%$ on the 4 th day. In $21 \%$ salinity $100 \%$ survival was recorded on the 1 st day but $0 \%$ (100\% mortality) on the next day.

Table 1. Survival rate (\%) of Anabas testudineus fingerlings at different salinity (\%) level in 60 day rearing period.

\begin{tabular}{lllll}
\hline \multirow{2}{*}{$\begin{array}{l}\text { Salinity } \\
(\%)\end{array}$} & \multicolumn{4}{c}{ Survival rate } \\
\cline { 2 - 5 } & 15 day & 30 day & 45 day & 60 day \\
\hline 0 & $100 \pm 0.0^{\mathrm{a}}$ & $100 \pm 0.0^{\mathrm{a}}$ & $100 \pm 0.0^{\mathrm{a}}$ & $100 \pm 0.0^{\mathrm{a}}$ \\
3 & $100 \pm 0.0^{\mathrm{a}}$ & $100 \pm 0.0^{\mathrm{a}}$ & $100 \pm 0.0^{\mathrm{a}}$ & $100 \pm 0.0^{\mathrm{a}}$ \\
6 & $100 \pm 0.0^{\mathrm{a}}$ & $100 \pm 0.0^{\mathrm{a}}$ & $100 \pm 0.0^{\mathrm{a}}$ & $100 \pm 0.0^{\mathrm{a}}$ \\
9 & $100 \pm 0.0^{\mathrm{a}}$ & $100 \pm 0.0^{\mathrm{a}}$ & $100 \pm 0.0^{\mathrm{a}}$ & $100 \pm 0.0^{\mathrm{a}}$ \\
12 & $85.0 \pm 5.0^{\mathrm{ab}}$ & $80.0 \pm 0.0^{\mathrm{bc}}$ & $67.5 \pm 2.5^{\mathrm{bcd}}$ & $60.0 \pm 10.0^{\text {cde }}$ \\
15 & $75.0 \pm 5.0^{\mathrm{bcd}}$ & $55.0 \pm 5.0^{\mathrm{de}}$ & $40.0 \pm 10.0^{\text {ef }}$ & $20.0 \pm 5.0^{\mathrm{f}}$ \\
\hline
\end{tabular}

Individual letters denote significantly different and the values are mean \pm SEM of duplicate groups of 10 fish.

Increasing trends of feed conversion ratio (FCR) was found with increasing salinity. Significantly lower FCR was found in A. testudineus fingerlings reared at $0 \%$ o salinity at 60 day $\left(1.55 \pm 0.05^{\mathrm{e}}\right)$ than that of other salinities and durations. The FCR values were not more than 2.80 at $0-6 \%$ salinity level at all durations of the experiment. Above $6 \%$ salinity level the FCR values notably increased and the highest FCR was obtained at 45 day $\left(5.20 \pm 0.20^{a}\right)$ at $15 \%$ o (Table 2$)$.

Table 2. Feed conversion ratio, FCR (Mean $\pm \mathrm{SEM})^{1}$ of Anabas testudineus fingerlings at 60 day rearing period.

\begin{tabular}{lllll}
\hline \multirow{2}{*}{$\begin{array}{l}\text { Salinity } \\
(\%)\end{array}$} & \multicolumn{4}{c}{ Feed conversion ratio (FCR) } \\
\cline { 2 - 5 } & 15 day & 30 day & 45 day & 60 day \\
\hline 0 & $1.75 \pm 0.05^{\mathrm{e}}$ & $2.00 \pm 0.10^{\text {cde }}$ & $1.64 \pm 0.46^{\text {de }}$ & $1.55 \pm 0.05^{\mathrm{e}}$ \\
3 & $2.30 \pm 0.10^{\text {cde }}$ & $1.85 \pm 0.05^{\mathrm{e}}$ & $2.75 \pm 0.35^{\mathrm{cd}}$ & $1.90 \pm 0.00^{\mathrm{de}}$ \\
6 & $2.35 \pm 0.05^{\text {cde }}$ & $2.40 \pm 0.20^{\text {cde }}$ & $2.80 \pm 0.10^{\mathrm{c}}$ & $2.05 \pm 0.15^{\text {cde }}$ \\
9 & $4.35 \pm 0.05^{\mathrm{ab}}$ & $4.15 \pm 0.35^{\mathrm{b}}$ & $4.10 \pm 0.10^{\mathrm{b}}$ & $4.20 \pm 0.10^{\mathrm{b}}$ \\
12 & $4.80 \pm 0.05^{\mathrm{ab}}$ & $4.70 \pm 0.10^{\mathrm{ab}}$ & $4.60 \pm 0.00^{\mathrm{ab}}$ & $4.70 \pm 0.20^{\mathrm{ab}}$ \\
15 & $4.85 \pm 0.05^{\mathrm{ab}}$ & $4.80 \pm 0.10^{\mathrm{ab}}$ & $5.20 \pm 0.20^{\mathrm{a}}$ & $4.95 \pm 0.25^{\mathrm{ab}}$ \\
\hline
\end{tabular}

Individual letters denote significantly different and the values are mean \pm SEM of duplicate groups of 10 fish.

Specific growth rate (SGR) decreased as the salinity increased. The highest SGR was found in $A$. testudineus at 60 day $\left(1.16 \pm 0.05^{a}\right)$ rearing period at $0 \%$ salinity than at other salinities and durations. The SGR value markedly decreased above 6\% salinity and the lowest SGR was observed at 30 day $\left(0.07 \pm 0.03^{\mathrm{d}}\right)$ rearing period at $15 \%$ salinity (Table 3 ). 
The average growth rate (AGR) of $A$. testudineus similarly decreased like SGR as the salinity increased. Highest AGR was found in A. testudineus fingerlings at 60 day (0.14 \pm $0.01^{\text {a) }}$ rearing period at $0 \%$ salinity than at other salinities and durations. Close differences of AGR values were observed between 0 and 6\%o salinity levels. The lowest AGR was detected at 45 day $\left(0.01 \pm 0.01^{\mathrm{f}}\right)$ at $15 \%$ salinity level (Table 4$)$.

Table 3. Specific growth rate, SGR (Mean \pm SEM) ${ }^{1}$ of Anabas testudineus fingerlings at 60 day rearing period.

\begin{tabular}{lcccc}
\hline \multirow{2}{*}{$\begin{array}{l}\text { Salinity } \\
(\%)\end{array}$} & \multicolumn{4}{c}{ Specific growth rate $($ SGR) } \\
\cline { 2 - 5 } & 15 day & 30 day & 45 day & 60 day \\
\hline 0 & $1.15 \pm 0.02^{\mathrm{a}}$ & $1.14 \pm 0.02^{\mathrm{a}}$ & $1.14 \pm 0.05^{\mathrm{a}}$ & $1.16 \pm 0.05^{\mathrm{a}}$ \\
3 & $0.97 \pm 0.01^{\mathrm{b}}$ & $0.99 \pm 0.01^{\mathrm{b}}$ & $0.96 \pm 0.02^{\mathrm{b}}$ & $0.99 \pm 0.00^{\mathrm{b}}$ \\
6 & $0.96 \pm 0.02^{\mathrm{b}}$ & $0.94 \pm 0.03^{\mathrm{b}}$ & $0.93 \pm 0.01^{\mathrm{b}}$ & $0.96 \pm 0.01^{\mathrm{b}}$ \\
9 & $0.17 \pm 0.01^{\mathrm{cd}}$ & $0.17 \pm 0.01^{\mathrm{cd}}$ & $0.18 \pm 0.01^{\mathrm{c}}$ & $0.18 \pm 0.01^{\mathrm{c}}$ \\
12 & $0.12 \pm 0.01^{\mathrm{cd}}$ & $0.08 \pm 0.01^{\mathrm{cd}}$ & $0.08 \pm 0.01^{\mathrm{d}}$ & $0.11 \pm 0.01^{\mathrm{cd}}$ \\
15 & $0.07 \pm 0.01^{\mathrm{d}}$ & $0.07 \pm 0.03^{\mathrm{d}}$ & $0.08 \pm 0.00^{\mathrm{d}}$ & $0.09 \pm 0.00^{\mathrm{cd}}$ \\
\hline
\end{tabular}

Individual letters denote significantly different and the values are mean \pm SEM of duplicate groups of 10 fish.

Table 4. Average growth rate, AGR (Mean \pm SEM) ${ }^{1}$ of Anabas testudineus fingerlings at day rearing period.

\begin{tabular}{|c|c|c|c|c|}
\hline \multirow{2}{*}{$\begin{array}{l}\text { Salinity } \\
(\% \text { o })\end{array}$} & \multicolumn{4}{|c|}{ Average growth rate (AGR) } \\
\hline & 15 day & 30 day & 45 day & 60 day \\
\hline 0 & $0.13 \pm 0.01^{a}$ & $0.12 \pm 0.01^{\mathrm{a}}$ & $0.11 \pm 0.03^{\mathrm{ab}}$ & $0.14 \pm 0.01^{\mathrm{a}}$ \\
\hline 3 & $0.11 \pm 0.01^{\mathrm{abc}}$ & $0.10 \pm 0.01^{\mathrm{abcd}}$ & & $0.12 \pm 0.02^{\mathrm{ab}}$ \\
\hline 6 & $0.09 \pm 0.01^{\mathrm{abcde}}$ & $0.09 \pm 0.03^{\text {abcde }}$ & $0.09 \pm 0.01^{\mathrm{abcde}}$ & $0.12 \pm 0.01^{\mathrm{ab}}$ \\
\hline 9 & $0.05 \pm 0.01^{\text {bcdef }}$ & $0.03 \pm 0.03^{\text {def }}$ & $0.03 \pm 0.01^{\text {def }}$ & $0.04 \pm 0.01^{\text {cdef }}$ \\
\hline 12 & $0.02 \pm 0.01^{\mathrm{ef}}$ & $0.03 \pm 0.00^{\mathrm{ef}}$ & $0.03 \pm 0.02^{\mathrm{def}}$ & $0.02 \pm 0.01^{\mathrm{ef}}$ \\
\hline 15 & $0.03 \pm 0.00^{\mathrm{ef}}$ & $0.02 \pm 0.03^{\mathrm{ef}}$ & $0.01 \pm 0.01^{\mathrm{f}}$ & $0.01 \pm 0.00^{f}$ \\
\hline
\end{tabular}

Individual letters denote significantly different and the values are mean \pm SEM of duplicate groups of 10 fish.

A. testudineus fingerlings showed high appetite towards food between 0 and $6 \%$ salinities in 60 day rearing period. At $9 \%$ salinity fingerlings showed very high appetite for almost half of the experimental period (27 days) and then showed high appetite from 29 to 43 days and low appetite during the last 15 days (45 to 60 days) of the experiment. The fingerlings showed high appetite during the first 9 days of the experiment, then moderate appetite up to 33 days and low appetite during the remaining days at the $12 \%$ salinity. At $15 \%$ salinity moderate appetite was observed for first 11 days and then low appetite for the remaining period. At 12 and 15\%o salinity levels sequential death 
occurred. A. testudineus fingerlings showed low appetite from the first day of the experiment and then $100 \%$ death occurred within 4 and 2 days at 18 and $21 \%$ o salinity levels, respectively (Table 5).

Table 5. Summary of daily feeding response of climbing Perch in different salinity regimes.

\begin{tabular}{|c|c|c|c|c|c|c|c|c|}
\hline \multirow[b]{2}{*}{ Day } & \multicolumn{8}{|c|}{ Salinity concentration $(\% \mathrm{o})$} \\
\hline & 0 & 3 & 6 & 9 & 12 & 15 & 18 & 21 \\
\hline 01 & VHA & VHA & VHA & VHA & HA & MA & LA & LA \\
\hline 03 & VHA & VHA & VHA & VHA & HA & MA & LA & $\mathrm{D}$ \\
\hline 05 & VHA & VHA & VHA & VHA & HA & MA & $\mathrm{D}$ & $\mathrm{D}$ \\
\hline 07 & VHA & VHA & VHA & VHA & HA & MA & $\mathrm{D}$ & $\mathrm{D}$ \\
\hline 09 & VHA & VHA & VHA & VHA & HA & MA & $\mathrm{D}$ & $\mathrm{D}$ \\
\hline 11 & VHA & VHA & VHA & VHA & MA & MA & $\mathrm{D}$ & $\mathrm{D}$ \\
\hline 13 & VHA & VHA & VHA & VHA & MA & LA & $\mathrm{D}$ & $\mathrm{D}$ \\
\hline 15 & VHA & VHA & VHA & VHA & MA & LA & $\mathrm{D}$ & D \\
\hline 17 & VHA & VHA & VHA & VHA & MA & LA & D & D \\
\hline 19 & VHA & VHA & VHA & VHA & MA & LA & D & D \\
\hline 21 & VHA & VHA & VHA & VHA & MA & LA & D & D \\
\hline 23 & VHA & VHA & VHA & VHA & MA & LA & $\mathrm{D}$ & D \\
\hline 25 & VHA & VHA & VHA & VHA & MA & LA & $\mathrm{D}$ & D \\
\hline 27 & VHA & VHA & VHA & VHA & MA & LA & $\mathrm{D}$ & D \\
\hline 29 & VHA & VHA & VHA & HA & MA & LA & $\mathrm{D}$ & D \\
\hline 31 & VHA & VHA & VHA & HA & MA & LA & $\mathrm{D}$ & $\mathrm{D}$ \\
\hline 33 & VHA & VHA & VHA & HA & MA & LA & $\mathrm{D}$ & D \\
\hline 35 & VHA & VHA & VHA & HA & LA & LA & $\mathrm{D}$ & $\mathrm{D}$ \\
\hline 37 & VHA & VHA & VHA & HA & LA & LA & $\mathrm{D}$ & D \\
\hline 39 & VHA & VHA & VHA & HA & LA & LA & $\mathrm{D}$ & D \\
\hline 41 & VHA & VHA & VHA & HA & LA & LA & $\mathrm{D}$ & D \\
\hline 43 & VHA & VHA & VHA & HA & LA & LA & $\mathrm{D}$ & $\mathrm{D}$ \\
\hline 45 & VHA & VHA & VHA & LA & LA & LA & $\mathrm{D}$ & $\mathrm{D}$ \\
\hline 47 & VHA & VHA & VHA & LA & LA & LA & $\mathrm{D}$ & $\mathrm{D}$ \\
\hline 49 & VHA & VHA & VHA & LA & LA & LA & D & $\mathrm{D}$ \\
\hline 51 & VHA & VHA & VHA & LA & LA & LA & D & D \\
\hline 53 & VHA & VHA & VHA & LA & LA & LA & D & $\mathrm{D}$ \\
\hline 55 & VHA & VHA & VHA & LA & LA & LA & $\mathrm{D}$ & $\mathrm{D}$ \\
\hline 57 & VHA & VHA & VHA & LA & LA & LA & D & $\mathrm{D}$ \\
\hline 60 & VHA & VHA & VHA & LA & LA & LA & $\mathrm{D}$ & D \\
\hline
\end{tabular}

$\mathrm{VHA}=$ Very high appetite, $\mathrm{HA}=$ High appetite, $\mathrm{MA}=$ Moderate appetite, $\mathrm{LA}=$ Low appetite, $\mathrm{D}=$ Death . 
The fish exhibited a normal response to threat between 0 and $9 \%$ salinity levels. At $12 \%$ o salinity the first 15 days showed normal response and the next 30 days showed hyper activeness and death was recorded at 45 days of rearing period. In 15\%o salinity moderate response was shown during the first five days hyper activeness during the next five days and death from 13 days. At 18\%o salinity A. testudineus fingerlings showed hyper activeness during the first two days and all death within four days. At $21 \%$ salinity death was recorded from the very first day and death occurred for all fingerlings within 2 days (Table 6).

Table 6. Summary of threat response of climbing Perch in different salinity regimes.

\begin{tabular}{|c|c|c|c|c|c|c|c|c|}
\hline \multirow[t]{2}{*}{ Day } & \multicolumn{8}{|c|}{ Salinity concentration (\%o) } \\
\hline & 0 & 3 & 6 & 9 & 12 & 15 & 18 & 21 \\
\hline 01 & $\mathrm{~N}$ & $\mathrm{~N}$ & $\mathrm{~N}$ & $\mathrm{~N}$ & $\mathrm{~N}$ & M & $\mathrm{H}$ & $\mathrm{D}$ \\
\hline 03 & $\mathrm{~N}$ & $\mathrm{~N}$ & $\mathrm{~N}$ & $\mathrm{~N}$ & $\mathrm{~N}$ & M & $\mathrm{H}$ & $\mathrm{D}$ \\
\hline 05 & $\mathrm{~N}$ & $\mathrm{~N}$ & $\mathrm{~N}$ & $\mathrm{~N}$ & $\mathrm{~N}$ & M & $\mathrm{D}$ & $\mathrm{D}$ \\
\hline 07 & $\mathrm{~N}$ & $\mathrm{~N}$ & $\mathrm{~N}$ & $\mathrm{~N}$ & $\mathrm{~N}$ & $\mathrm{H}$ & $\mathrm{D}$ & $\mathrm{D}$ \\
\hline 09 & $\mathrm{~N}$ & $\mathrm{~N}$ & $\mathrm{~N}$ & $\mathrm{~N}$ & $\mathrm{~N}$ & $\mathrm{H}$ & $\mathrm{D}$ & $\mathrm{D}$ \\
\hline 11 & $\mathrm{~N}$ & $\mathrm{~N}$ & $\mathrm{~N}$ & $\mathrm{~N}$ & $\mathrm{~N}$ & $\mathrm{H}$ & $\mathrm{D}$ & $\mathrm{D}$ \\
\hline 13 & $\mathrm{~N}$ & $\mathrm{~N}$ & $\mathrm{~N}$ & $\mathrm{~N}$ & $\mathrm{~N}$ & $\mathrm{D}$ & $\mathrm{D}$ & $\mathrm{D}$ \\
\hline 15 & $\mathrm{~N}$ & $\mathrm{~N}$ & $\mathrm{~N}$ & $\mathrm{~N}$ & $\mathrm{~N}$ & $\mathrm{D}$ & $\mathrm{D}$ & $\mathrm{D}$ \\
\hline 17 & $\mathrm{~N}$ & $\mathrm{~N}$ & $\mathrm{~N}$ & $\mathrm{~N}$ & $\mathrm{H}$ & $\mathrm{D}$ & $\mathrm{D}$ & $\mathrm{D}$ \\
\hline 19 & $\mathrm{~N}$ & $\mathrm{~N}$ & $\mathrm{~N}$ & $\mathrm{~N}$ & $\mathrm{H}$ & $\mathrm{D}$ & $\mathrm{D}$ & $\mathrm{D}$ \\
\hline 21 & $\mathrm{~N}$ & $\mathrm{~N}$ & $\mathrm{~N}$ & $\mathrm{~N}$ & $\mathrm{H}$ & $\mathrm{D}$ & $\mathrm{D}$ & $\mathrm{D}$ \\
\hline 23 & $\mathrm{~N}$ & $\mathrm{~N}$ & $\mathrm{~N}$ & $\mathrm{~N}$ & $\mathrm{H}$ & D & D & $\mathrm{D}$ \\
\hline 25 & $\mathrm{~N}$ & $\mathrm{~N}$ & $\mathrm{~N}$ & $\mathrm{~N}$ & $\mathrm{H}$ & D & D & $\mathrm{D}$ \\
\hline 27 & $\mathrm{~N}$ & $\mathrm{~N}$ & $\mathrm{~N}$ & $\mathrm{~N}$ & $\mathrm{H}$ & D & D & $\mathrm{D}$ \\
\hline 29 & $\mathrm{~N}$ & $\mathrm{~N}$ & $\mathrm{~N}$ & $\mathrm{~N}$ & $\mathrm{H}$ & D & D & D \\
\hline 31 & $\mathrm{~N}$ & $\mathrm{~N}$ & $\mathrm{~N}$ & $\mathrm{~N}$ & $\mathrm{H}$ & D & D & $\mathrm{D}$ \\
\hline 33 & $\mathrm{~N}$ & $\mathrm{~N}$ & $\mathrm{~N}$ & $\mathrm{~N}$ & $\mathrm{H}$ & D & D & $\mathrm{D}$ \\
\hline 35 & $\mathrm{~N}$ & $\mathrm{~N}$ & $\mathrm{~N}$ & $\mathrm{~N}$ & $\mathrm{H}$ & D & D & $\mathrm{D}$ \\
\hline 37 & $\mathrm{~N}$ & $\mathrm{~N}$ & $\mathrm{~N}$ & $\mathrm{~N}$ & $\mathrm{H}$ & D & D & D \\
\hline 39 & $\mathrm{~N}$ & $\mathrm{~N}$ & $\mathrm{~N}$ & $\mathrm{~N}$ & $\mathrm{H}$ & D & D & $\mathrm{D}$ \\
\hline 41 & $\mathrm{~N}$ & $\mathrm{~N}$ & $\mathrm{~N}$ & $\mathrm{~N}$ & $\mathrm{H}$ & D & D & $\mathrm{D}$ \\
\hline 43 & $\mathrm{~N}$ & $\mathrm{~N}$ & $\mathrm{~N}$ & $\mathrm{~N}$ & $\mathrm{H}$ & D & D & D \\
\hline 45 & $\mathrm{~N}$ & $\mathrm{~N}$ & $\mathrm{~N}$ & $\mathrm{~N}$ & D & D & D & $\mathrm{D}$ \\
\hline 47 & $\mathrm{~N}$ & $\mathrm{~N}$ & $\mathrm{~N}$ & $\mathrm{~N}$ & D & D & D & D \\
\hline 49 & $\mathrm{~N}$ & $\mathrm{~N}$ & $\mathrm{~N}$ & $\mathrm{~N}$ & D & D & D & $\mathrm{D}$ \\
\hline 51 & $\mathrm{~N}$ & $\mathrm{~N}$ & $\mathrm{~N}$ & $\mathrm{~N}$ & D & D & D & $\mathrm{D}$ \\
\hline 53 & $\mathrm{~N}$ & $\mathrm{~N}$ & $\mathrm{~N}$ & $\mathrm{~N}$ & D & D & D & $\mathrm{D}$ \\
\hline 55 & $\mathrm{~N}$ & $\mathrm{~N}$ & $\mathrm{~N}$ & $\mathrm{~N}$ & $\mathrm{D}$ & D & D & D \\
\hline 57 & $\mathrm{~N}$ & $\mathrm{~N}$ & $\mathrm{~N}$ & $\mathrm{~N}$ & D & D & D & D \\
\hline 60 & $\mathrm{~N}$ & $\mathrm{~N}$ & $\mathrm{~N}$ & $\mathrm{~N}$ & $\mathrm{D}$ & $\mathrm{D}$ & $\mathrm{D}$ & $\mathrm{D}$ \\
\hline
\end{tabular}

$\mathrm{N}=$ Normal response, $\mathrm{M}=$ Moderate response, $\mathrm{H}=$ Hyperactive, $\mathrm{D}=$ Death. 
Findings of the study showed that $A$. testudineus can tolerate a regime of 0 to $9 \%$ salinity. High growth performance in terms of total length (TL), body weight (BW), specific growth rate (SGR), feed conversion ratio (FCR) and average growth rate (AGR) were recorded from 0 to $6 \%$ salinity level. This is an indication that the fish were perfectly able to regulate their body physiology within this regime. One hundred per cent mortality was recorded in 18 and $21 \%$ salinity which indicates osmo-regulatory failure in fish.(3) Survival rate of $100 \%$ in 0 to $9 \%$ salinity reveals that the fish can withstand an intermediate salinity range which may be because of the ability of the body fluids to function at least for short time in an abnormal range of internal osmotic and ionic concentrations. Tarer(6) recorded significant differences in Labeo rohita and Cirrhinus mrigala in their tolerance of salinity and found Labeo rohita (Rohu) more tolerant towards salinity (up to $7 \%$ ), which supports the present findings. Kasim ${ }^{(7)}$ found variable behavioral patterns in different carps at different salinities, where common carp showed higher tolerance to salinity than that of rohu and mirigal. Kliambi and Zdinak ${ }^{(8)}$ while working with grass carp fingerlings recorded 71 - 90\% mortality in 24 hours under 15\%o salinity. As reported by Nugon ${ }^{(9)}$ juveniles of O. aureus, O. niloticus and Florida red tilapia exhibited good survival (> 81\%) in salinity regimes up to $20 \%$, with moderate survival of O. aureus (54\%) and Florida red tilapia (33\%) at $35 \%$ salinity.

Feed conversion ratio values found in fish reared at 0,3 and $6 \%$ indicate good growth rate. Better FCR $(1.55 \pm 0.05 \mathrm{e})$ was obtained at $0 \%$ s salinity at 60 days. The efficiency of feed conversion depends on many factors but the best response is probably strongly related to optimize the environment to approximate that to which the fish is accustomed ${ }^{(10)}$. Akand et al.(11) found that the FCR value of Heteroneustes fossilis to range from 2.0 to 2.7 .

In terms of specific growth rate (SGR) the highest SGR $\left(1.16 \pm 0.05^{\mathrm{a}}\right)$ was detected at $0 \%$ at 60 days duration, but SGR decreased with increasing salinity. This finding resembles the Medawars ${ }^{(12)}$ fifth law "the specific growth rate declines more and more slowly as the organism increases in age". Pike silverside, Chrostoma estor estor can tolerate salinity up to $5 \%$ but SGR and survival rates are reduced at salinities of $10 \%$ and above. ${ }^{(13)}$

A. testudineus show nearly similar average growth rate (AGR) in 0 to $6 \%$ salinities at 60 days rearing period. Maximum AGR $\left(0.14 \pm 0.01^{\mathrm{a}}\right)$ was recorded in $0 \%$ salinity at 60 days and lower AGR $\left(0.01 \pm 0.01^{\mathrm{f}}\right)$ was found in $15 \%$ o salinity at 45 days. Higher AGR of the fish suggest that the fish were able to regulate osmotic pressure of the body fluid; this was in agreement with suggestions of Nikolsky(2), the more the osmo-regulatory adaptation, lesser the difference between the compositions and pressures of the internal fluid of the organism and its external environment. The migration of fish from fresh to seawater will normally lead to increase in osmotic concentration of the fish's blood serum and change in ionic contents and decrease the rate of daily gain. ${ }^{(14,15)}$ 
The restlessness or hyper-activeness or erratic behavior in high salinities indicates fast rate at which the fish approach their tolerance limits and loss of water to external medium from the body. In case of $A$. testudineus (from this research) normal response was found up to $9 \%$ salinity and then hyper-activeness or erratic behavior or death at 12 to $21 \%$. Fish move to preferred position in salinity gradient, to indicate salinity preferences in a desired situation ${ }^{(4)}$. Such changes with increased salinity are indication that the salinities were near or exceeded the tolerance limits of the fish. Moderate and normal responses represented the near and far tolerance limits, respectively.

High appetite of $A$. testudineus was recorded in 0 to $6 \%$ salinity level in this study and sequentially lowered and death occurred at 12 to $21 \%$. The high appetite displayed by the fish towards food is an indication that fish body metabolism can still be maintained or regulated in these salinities, while low appetite is an indication of near or total body metabolic break down. Chavez et al.(16) observed Oreochromis niloticus to show high appetite between 0 and $7 \%$ salinities.

For aquaculture purpose, the findings of this study suggest that $A$. testudineus fingerlings can be cultured in aquatic environment with salinities ranging from $0-6 \%$ which confirm high production and better economic return. However, the most preferred salinity was $3 \%$.

\section{Acknowledgements}

The authors are grateful to the supports provided by Department of Fisheries, University of Dhaka and also the Ministry of Science and Technology for National Science and Technology Fellowship, 2013.

\section{References}

1. Muir C and J Roberts 1995. Metabolic cost of acute physical stress in juvenile steelhead. Trans. Amer. Fish. Soc. 116: 257-263.

2. Nikolsky GV 1963. The Ecology and Behavioral Response of Fishes in Different Salinities. Academic Press, London.

3. Holliday FGT 1965. Osmo regulation in marine teleost eggs and larvae. Cal. Coop. Ocean. Fish. 10: 89-95.

4. Baggerman B 1959. The Role of External Factors and Hormones in Migration of Sticklebacks and Juvenile Salmon. In: Gorbman, A. (Ed.), Comparative Endocrinology. Wiley, New York, USA, pp. 24-37.

5. Hopkins KD 1992. Reporting fish growth: A review of the basics. J. World Aquac. Soc. 23(3): 173-179.

6. Tarer SR 2000. The effect of salinity on the growth and tolerance of Labeo rohita and Cirrhinus mrigala, M. Phil. Thesis, Department of Zoology and Fisheries, University of Agriculture, Faisalabad, Pakistan.

7. Kasim HM 1983. Salinity tolerance of certain freshwater fishes. Ind. J. Fish. 30: 46-54. 
8. Kilambi RV and A Zdinak 1980. The effects of acclimation on the salinity tolerance of grass carp, (Ctenopharyngodon idella). J. Fish Bio. 17: 171-175.

9. Nugon RW 2003. Salinity tolerance of juveniles of four varties of tilapia. M.Sc. Thesis, Louisiana State University, USA.

10. Canagaratnam P 1966. Observation of feed efficiency and conversion and overall growth of Nile Tilapia, Oreochromis niloticus in varied salinities. Asian J. Agri. Sci. 4: 102-123.

11. Akand AM, ML Mia and MM Haque 1989. Effect of dietary protein level on growth, food conversion and body composition of Shingi, Heteropneustes fossilis. Aquaculture 77: $175-180$.

12. Medawars L 1945. Physiology of salinity tolerance in tilapia an update of basic and applied aspects. J. Aquat. Living Resour. 2: 91-97.

13. Martinez-palacios CA, Barriga Tovar E, Taylor JF, Rios Dura NG, Ross LG 2004. Effect of salinity on growth and survival of Chirostoma estor estor using a simple video technique for remote measurement of length and mass of larval and juvenile fishes. Aquaculture 209: 369-377.

14. Gordon MS 1959. Ionic regulation and determination of specific growth rate in the Brown trout (Salmo trutta). J. Exp. Biol. 36: 227-252.

15. Miles HM and LS Smith 1968. Ionic regulation in migrating juvenile Coho salmon, Oncorhynchus kisutch. J. Sea Res. 26: 281-398.

16. Chavez MOP, C Le Rouzic, M Cauty, T Edery and Prunet M 1983. Expression of the prolactin receptor (t1PRL-R) gene in tilapia Oreochromis niloticus, tissue distribution and cellular localization in osmoregulatory organs. J. Mol. Endocr. 24(2): 215-224.

(Manuscript received on 29 November, 2015; revised on 14 January, 2016) 